
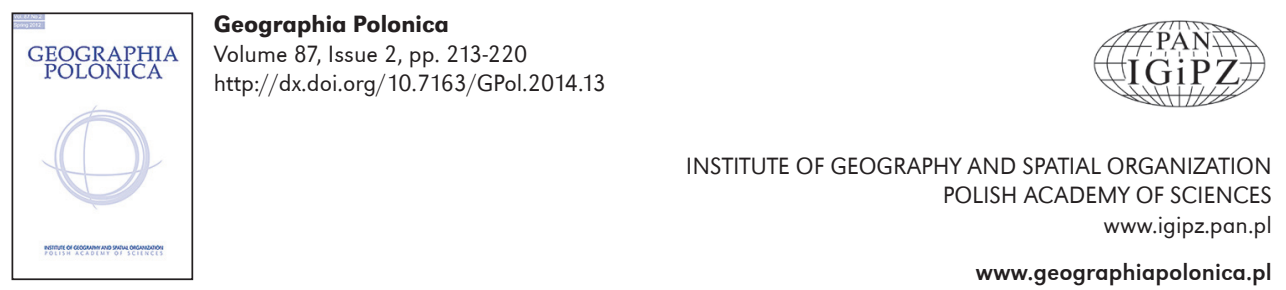

\title{
TOWARDS AN INTERNATIONAL APPROACH FOR GEOGRAPHY EDUCATION
}

\author{
Joop van der Schee ${ }^{1,2}$ - John Lidstone ${ }^{1,3}$ - Clare Brooks ${ }^{4}$ \\ ${ }^{1}$ Co-chairs of the IGU Commission on Geographical Education \\ ${ }^{2}$ Faculty of Geosciences \\ University of Utrecht \\ Heidelberglaan 2, 3584 CS Utrecht: The Netherlands \\ e-mail: j.a.vander.schee@vu.nl \\ ${ }^{3}$ Cultural and Language Studies in Education \\ Queensland University of Technology \\ Victoria Park Road, Kelvin Grove, Brisbane, Queensland 4059: Australia \\ e-mail: j.lidstone@qut.edu.au \\ ${ }^{4}$ Institute of Education \\ University of London \\ 20 Bedford Way, London WC1H OAL: United Kingdom \\ e-mail: C.Brooks@ioe.ac.uk
}

\begin{abstract}
"Geography education is indispensable to the development of responsible and active citizens in the present and future world" is one of the main statements in the International Charter on Geographical Education. This charter was edited in 1992 by Haubrich, chair of the Commission on Geographical Education of the International Geographical Union (IGU). Twenty years later this statement is still true. Geography educators all over the world are looking for ways to talk with young people about their image of their world and to help them to develop their knowledge, skills and ideas about the complex world we live in. However, different ideas exist about what geography we should learn and teach and how. The Commission on Geographical Education of the International Geographical Union tries to help to improve the quality and position of geography education worldwide, promoting the dissemination of good practices and research results in the field of geography education.
\end{abstract}

\section{Key words}

geography education - children's geographies - Rome declaration • research in geographical education - international co-operation 


\section{Geography education, what are they talking about?}

Figure 1 shows a map of the Netherlands in 2040 as seen by 13 - to 15-year-old pupils. In 2010 the Education Section of the Royal Dutch Geography Society asked geography teachers all over the Netherlands to participate in a research project in which pupils in lower secondary geography classes were given the assignment of drawing a map of the Netherlands as they thought the map would look in the year 2040. Almost 700 pupils participated. The map in Figure 1 shows an overview of features that were presented in the majority of the individual maps (Adang et al. 2010). The major changes expected by many pupils are striking when compared with today's situation. Many pupils expect that, in 2040, large areas in the western part of the Netherlands will be flooded by a rising sea level. To compensate this loss of land, many pupils incorporate some border areas of Belgium and Germany into the Netherlands and opt for land reclamation projects at places where inland seas are now. In addition, the summary map shows huge new infrastructural projects like a tulip-shape island in the North Sea, a bridge to England, and a long tunnel between Belgium and Germany. This map reflects the discussion within and outside Dutch geography lessons about the impact of climate change and sea-level rise. The map also shows pupils' trust in the power of modern technology and politics to solve today's problems. These results are in line with research findings from Wevers (2011), who participated in an international project 'Young people; cross-cultural views and futures' that investigated the images of the future held by 12-13 year-old Dutch pupils. Wevers reports that her pupils have a positive image of their own personal future, but that they are quite pessimistic about the world they live in with reference to environmental issues, wars and natural hazards. At the same time, pupils believe in technological solutions for problems we face now.
The map in Figure 1 gives us food for thought; for policymakers, pupils and geography teachers. The map can be used in geography classrooms to discuss possible and preferred futures (Hicks 2002). What were the ideas used by children to draw their maps the way they did? And where do these children develop these ideas? In geography classrooms? Or are the internet and TV more important? Children entering geography classrooms are no tabula rasa. Young people's geographies are important. Children's geographies should not be the same as the geography curriculum, but "that what the geography curriculum may require can be significantly enhanced through connecting it with their geographies" (Catling 2011: 21). Good geography teachers are able to support the development of children's understanding of their personal geographies through insight regarding geographical processes and patterns, in encouraging debate about topical interests and issues and through involving children in learning from each other. Both children's and teachers' geographies are involved here (Catling 2011: 26-27). Thoughtful geography teachers are able to listen to children's geographies and transform academic geographical knowledge in a way that helps young people to understand the world they live in better.

But how do we do that? In most countries time for geography teaching is very limited. So an important question is what and how do we learn about geography? For many people geography is the subject that asks you to know the names of cities, regions, rivers and mountains. In addition, geography is the subject with a huge vocabulary allowing for the description of phenomena on Planet Earth, with concepts like suburbanization, abrasion, wadi and landslide. To many outsiders, geography may look like a huge heap of facts and concepts without any focus. It seems to be a thousand miles wide, but just a few inches deep. This image is unfortunately reinforced by TV quizzes. Of course it is useful to know names and locations of countries and capitals to understand what is where (van der Schee 2012). Without basic map knowledge 
and some agreement on what to call certain phenomena, any talk about today's world is quite difficult. Geography is also a good training in map skills, learning skills and thinking skills. But this not the whole story. Geography helps to develop a range of perspectives and "this is less likely to be achieved if one sticks solely to specific instances or, far worse, learning and thinking skills development as if these were in themselves a worthwhile 'end'"(Lambert 2011). Geography is more than a basic vocabulary or syntax, it also has

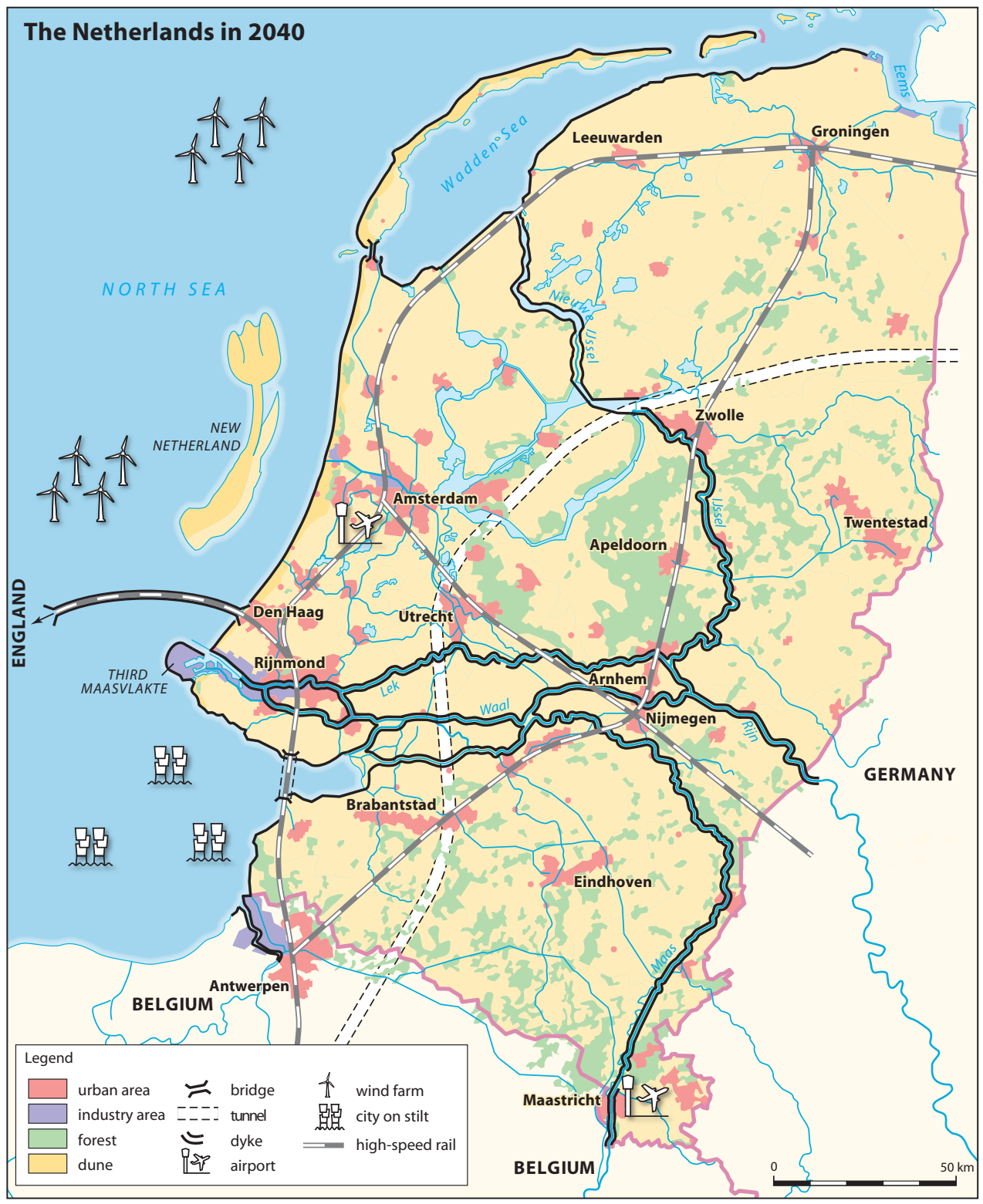

Figure 1. Map of the Netherlands in 2040 as seen by 13- to 15-year-old pupils in 2010 Source: Adang et al. 2010 
its semantics. Its focus is on meaningful learning about Planet Earth and getting a different view. A different view means a view that is different from what we often see in the media, and also using different perspectives. Geography is more than facts and concepts, it is the fascinating story of people that live on Planet Earth at different spots, in different ways, in conditions that change continuously. Key concepts are diversity, interaction, change, and perspective (Taylor 2008). Geography is concerned with human-environment interactions in the context of specific places and locations, and with issues that have a strong geographical dimension like natural hazards, climate change, energy supplies, land use, migration, urbanisation, poverty and identity (Haubrich 1992).

In spite of the modern aims of geography education, the position of geography in education is not strong. There are many questions unanswered about geography teaching and there is still much work to do in research in geography education. However, sometimes there are new starts and hopeful initiatives. The next two sections of this contribution give information about geography teaching and research in geography education. The following information gives a brief impression of recent important developments in these areas. The first one is the 2013 "Rome Declaration on Geographical Education in Europe" (www.igu-cge.org) and the second the 2013 US "Roadmap for 21st century Geography Education: Geography Education Research" (Bednarz et al. 2013). After these two sections we will give a short overview of the work of the IGU Commission on Geographical Education and conclude that an international approach is necessary.

\section{The 2013 Rome Declaration}

The Rome Declaration is a joint reaction of the European Geography Community to recent threats to reduce or even abolish geography content from school curricula (Ottens 2013). In Rome, four organisations met to discuss the difficult and tenuous position of geography in schools in many European countries. EUGEO, the Association of European Geographical Societies, AlIG, the Italian Association of Geography Teachers, EUROGEO, the association of European Geographers, and the IGU Commission on Geographical Education signed a declaration that set minimum requirements for geography in schools:

- to recognize the educational value afforded by the study of geography as an essential school subject;

- to acknowledge its strategic role for realizing active citizenship and balanced social, economic and environmental development;

- to apply geographical knowledge, skills and understanding to the main issues linked with processes of change in society, nature and the environment at local, national, European and global levels;

- to provide sufficient time for teaching geography in schools; and

- to take care that the teaching of geography is limited to teachers with a qualified training in geography and geography education.

This set of minimum requirements will be further developed into a Strategic Plan for Geography Education and will be discussed at the 2014 IGU Regional Conference in Krakow. Krakow can be the venue for an international discussion about the position and development of geography education, with participants from all over the world.

\section{The US Road Map for Research in Geography Education}

Not only in Europe is the state of geography education a concern. With financial support from the US National Science Foundation, the US Road Map Project responds to the growing recognition that Americans lack the critical geographic understanding and reasoning skills that will be required for careers and civic life in the 21st century. The Road Map Project brought together experts in geography, science, education, and research from across the US to create a set of landmark reports focusing on key issues for educational improvement: 
instructional materials for students, education of teachers, assessment in geography, and a research agenda for geography education (Edelson \& Pitts 2013). Regarding the research agenda Bednarz et al. (2013) state that "we need better and more research before we can understand even the most fundamental ways individuals develop proficiency in geography". The report focuses on two questions. The first question is "What areas of research will be most effective in improving geography education on a large scale?" and the second is "what strategies and methodologies can relevant research communities develop and adopt to maximize the cumulative impact of education research in geography?' The Geography Education Research Committee of the Road Map for 21st Century Geography Education Project suggests careful consideration of education research in related fields, as well as the creation of a framework for geography education research. The report concludes with 13 recommendations to improve research in geography education to develop a more geographically literate society. These recommendations vary from "The Committee recommends research about fieldwork and its impact on learning geography, skills, and practices" to "The Committee recommends the creation or designation of an institution to coordinate the implementation, dissemination, and knowledge transfer of research results". The Road Map for Geography Education concludes by saying that "high-quality research in geography education is needed and can serve to move the understanding of teaching and learning geography forward" (Bednarz et al. 2013).

It is thus time to re-engage with geography education research (Lambert 2010). Quality research in geography education is a concern in more and more countries in the world. So it is high on the agenda of the IGU Commission on Geography Education. An interesting new start is made by GEReCo, a recent group of research-active geography educators based in British universities, with the purpose of creating and disseminating research in geography education (Butt 2010).

\section{Aims and projects of the Commission on Geographical Education}

Geography teaching and learning differ from country to country. The position of geography is also different in different countries, and often even within countries. To inform people about these differences, the Commission on Geographical Education started a WIKI on Geographical Education at its website www.igu-cge.org. Although in many countries the position of geography in school curricula is under pressure, many millions of pupils all over the world follow geography lessons in primary and secondary education. Some of them enjoy the subject and the way their teacher presents the subject so much that they continue to study geography in tertiary education as well. The Commission on Geographical Education of the International Geographical Union tries to improve the position and quality of teaching and learning of geography.

The purpose of the Commission is to promote geographical and environmental education globally. In order to accomplish this goal, the activities of the Commission include (I) the organization of international conferences; (II) the coordination of international and regional research projects; (III) the publication of a journal, International Research in Geographical and Environmental Education, newsletters and conference proceedings; and (IV) co-sponsorship of the International Geography Olympiad. In relation to these aims, the Steering Committee of the Commission has identified seven international projects for the period 2012-2016. All members of the Commission on Geographical Education are invited to participate in these projects:

1. The establishment of virtual geography communities of practice. This proposal encourages and enables geography educators in various parts of the world to engage and work together, communicating with each other and sharing materials such as curricula, individual lessons, learning objects and assessment 
items, virtually. This includes also promotional materials for geography as an essential part of education at all levels.

2. The publication of an edited book on geography education practice and research.

3. The publication of an edited book on "Geospatial technologies and geography education in a changing world".

4. The preparation of a digital list of significant books and other publications on geographical education to help those who want to read about research and development in geography education. This list to be published on www.igu-cge.org.

5. The creation of a Geography Education Doctoral and PhD collection to enhance our knowledge of geographical and environmental education. The collation from around the world of the authors, titles, publishers and abstracts of successful doctoral theses and PhD studies in geographical and environmental education, from all nations and in national languages will be brought together in an on-line list on the IGU-CGE website available for everyone. The abstracts should be in English, and between 100 and 300 words long.

6 . The development of a network to support and connect early-career researchers in geography education internationally.

7. The continued support and sponsorship of the IGU Olympiad Task Force as an important way to promote geography, to stimulate understanding between young people and to help to improve the quality of school geography worldwide. Geography educators from different countries report that the content of the tests of the Olympiad contribute positively to the debate on the importance of geography as a secondary school subject (van der Schee \& Kolkman 2010).

These projects show how the Commission on Geographical Education supports the work of geography teachers, as well as the work of researchers in geography education worldwide. The Commission communicates on a regular basis with nearly 700 geographers in 75 countries. Geography in schools, as well as research in geography education, needs support if the teaching and learning of geography are to improve. Both main areas of work are important.

\section{Conclusion}

Because location, interconnectedness and identity are key factors in today's society, the position of geography should not be in jeopardy. Geographical knowledge and geospatial technologies offer unique opportunities for policymakers to be shown that we cannot make sense of the modern world without geography. Focusing on a limited number of vital central issues like water, energy, food and housing, as well as on the unique integrated human-nature way of geographical thinking, the position of geography in education can be strengthened. In addition, because helping young people to find their way in the world is one of most important things we can do, geography education should not be threatened. Nevertheless we often see that the position and quality of geography education and geography education research is 'below sealevel'. The community of geographers in education has to organise itself better to take advantage of the opportunities mentioned earlier. It is necessary that the geographical community communicates a clear view on the role of geography education in a digital era in which geospatial technologies seem to be all important. Using Google Earth, Youtube, Skype, Facebook, serious games and virtual fieldwork offer great opportunities for geography education. Of course it is important to stay alert and critical using geospatial technologies, for geography education is more than using the 21st century's newest tools and cool pictures, just as geography is more than spatial analysis. "To really understand the world you need to get under the skin of the people and places" as Michael Palin said (Lambert \& Jones 2013: 10). In geography education, knowledge and discussion of how people live at different places is as important as geographical skills. Geographical analysis and evaluation, as well as a critical use of geographical knowledge 
and geospatial technologies are of considerable significance in developing young people's awareness of major contemporary issues. It is important to help geography teachers train students to develop an open mind and look with a different view. Although it is necessary to learn a basic amount of facts and concepts in geography, making meaning beyond facts and concepts is the ultimate goal. Geography education is a lesson in how to think geographically, and there is no single way to do that (Morgan 2013: 274). Geographical knowledge is constructed socially, and young people should be trained to develop different views in looking at phenomena and processes in the world they inhabit. Butt (2011: 10) states that "young people should be able to use their geography education to help them become more autonomous decision makers, better citizens and more enquiring individuals" and "geography is a way of seeing, placing considerable weight on the importance of promoting children's abilities to think geographically so that they can make sense of the world". This vision needs to be transmitted clearly by all stakeholders.

The Commission on Geographical Education of the International Geographical Union consists of a group of people who believe that good geography education can make a difference. The Commission also advocates strongly the importance of geography

\section{References}

Adang A., Notte H., van der Schee J., 2010. De toekomst in kaart. Nederland in 2040 getekend door onderbouw leerlingen van het voortgezet onderwijs. Amsterdam: Onderwijscentrum VU.

Bednarz S.W., Hefrron S., Huynh N.T. (eds.), 2013. A road map for 21st century geography education. Geography education research (A report from the Geography Education Research Committee of the Road Map for 21st Century Geography Education Project). Washington: Association of American Geographers. education research. This is seen to be highly important for the field of geography education. As Lambert (2010: 85) wrote in a special forum in International Research in Geographical and Environmental Education on perspectives on research in geography education:

"If there is a field of Geography Education Research, it surely needs to be more substantial than education research with a geographical hue. It seems to me that Geography Education Research is concerned with two big ideas, geography and education, and how they are related. What this means most obviously is the study of how geography contributes to education."

In today's network society, international exchange of good practices as well as international research in geography education can help to improve the contribution geography education makes to today's world.

\section{Acknowledgements}

The authors would like to thank the former chair of the IGU Commission on Geographical Education, Professor Lex Chalmers, for his comments on a first draft of this paper.

\section{Editors' note:}

Unless otherwise stated, the sources of tables and figures are the author(s), on the basis of their own research.

ButT G., 2010. Perspectives on research in geography education. International Research in Geographical and Environmental Education, vol. 19, no. 2, pp. 79-82.

Butt G., 2011. Introduction [in:] G. Butt (ed.), Geography, education and the future. London: Continuum, pp. 1-11.

CatLing S., 2011. Children's geographies in the primary school [in:] G. ButT (ed.), Geography, education and the future. London: Continuum, pp. 15-29.

Edelson D.C., Pitts V.M., 2013. Charting the course. A road map for 21 st century geography 
education. Executive overview. Washington: National Geographic Society.

HAUBRICH H., 1992. International charter on geographical education. Freiburg: Commission on Geographical Education IGU, http://www. igu-cge.org/ [25 January 2014].

Hicks D., 2002. Lessons for the future. The Missing Dimension in Education. London: Routledge.

LAMBERT D., 2010. Geography education research and why it matters. International Research in Geographical and Environmental Education, vol. 19, no. 2, pp. 83-86.

LAMBERT D., 2011. Reframing school geography: a capability approach [in:] G. ButT (ed.), Geography, education and the future. London: Continuum, pp. 127-140.

LAMBERT D., JONES M., 2013. Introduction. Geography education, questions and choices [in:] D. LAMBert, M. Jones (eds.), Debates in geography education. London: Routledge, pp. 1-14.

MoRgan J., 2013. What do we mean by thinking geographically? [in:] D. LAMBERT, M. JONES (eds.),
Debates in geography education. London: Routledge, pp. 273-281.

OtTens H., 2013. Reflections on geography education in Europe. J-Reading, Journal of Research and Didactics in Geography, vol. 2, no. 2, pp. 97-100.

TAYLOR L., 2008. Key concepts and medium term planning. Teaching Geography, vol. 33, no. 2, pp. 50-54.

VAN DeR Schee J., 2012. Geographical education in a changing world. J-Reading, Journal of Research and Didactics in Geography, vol. 0, no. 1, pp. 11-15.

van der Schee J., Kolkman R., 2010. Multimedia tests and geographical education: the 2008 International Geography Olympiad. International Research in Geographical and Environmental Education, vol. 19, no. 4, pp. 283-293.

WEVERS I., 2011. Toekomstbeelden van jongeren in relatie tot hun aardrijkskunde-onderwijs. Utrecht: Utrecht University (master thesis). 